\title{
Terorisme Dan Agama Dalam Perspektif Charles Kimball
}

\author{
Selvia Santi \\ UIN Sunan Kalijaga Yogyakarta \\ silvi.humaniora@gmail.com
}

\section{ABSTRACT}

In this article the author tries to answer the research question, is it true that religion has encouraged terrorist groups to launch their acts of terror? To answer that, the author will use the thought of a comparative religious scholar who once served in the conflict areas of the Middle East, Charles Kimball, which is described in his book "When Religion Becomes Evil". Kimball used a historical, cultural, and political approach to explain his thought about relation between religion and violence. He identified five signs that people have to be alert; the signs when religious understanding has deviated so that it will bring disaster. These five signs are absolute truth claims, blind obedience, establishing the "ideal" time, the end justifies any means, and declaring holy war. The conclusion that can be drawn is that terrorist actors basically only use religion as a justification for their actions.

Keywords: terrorism, Middle East, religion, Charles Kimball

\section{ABSTRAK}

Dalam artikel ini penulis berusaha menjawab pertanyaan penelitian, benarkah agama telah mendorong kelompok-kelompok teroris untuk melancarkan aksiaksi teror mereka? Untuk menjawabnya, penulis akan menggunakan pemikiran seorang pakar perbandingan agama yang pernah bertugas di wilayah-wilayah konflik di Timur Tengah, yaitu Charles Kimball, yang tertuang dalam bukunya "When Religion Becomes Evil". Kimball menggunakan pendekatan sejarah, budaya, dan politik dalam menelusuri kaitan antara agama dan aksi kekerasan. 
la pun mengindentikasi lima tanda yang perlu diwaspadai, yaitu tanda-tanda ketika pemahaman agama telah melenceng sehingga akan membawa bencana. Kelima tanda itu adalah klaim kebenaran mutlak, kepatuhan buta, membangun zaman ideal, tujuan menghalalkan segala cara, dan menyerukan 'perang suci'. Kesimpulan yang dapat diambil adalah bahwa para pelaku teroris pada dasarnya hanya menggunakan agama sebagai alat pembenaran bagi tindakan mereka.

Kata kunci: terorisme, Timur Tengah, agama, Charles Kimball

\section{Pendahuluan}

Terorisme merupakan salah satu isu yang sangat banyak mewarnai pemberitaan media cetak maupun elektronik, serta media sosial. Aksi-aksi terorisme terjadi di berbagai kawasan dunia, mulai Asia hingga Eropa, namun yang sangat banyak mendapat sorotan selama beberapa tahun terakhir adalah terorisme yang terjadi di Timur Tengah.

Konflik sektarian di Timur Tengah menyajikan gambar-gambar mengerikan, pasukan yang bersembunyi di balik bangunan rumah yang terbuat dari batu-batu yang nampak tak berwarna, seorang ayah yang berlumuran darah tengah membawa lari anaknya, seorang anak yang terkena tembakan dikepala, hingga mayat-mayat yang dibiarkan di pinggir jalan karena orang-orang lain berusaha menyelamatkan dirinya sendiri, perempuan yang dikurung di dalam kandang, lalu diarak keliling kota oleh pasukan Jaysh al Islam, pemenggalan kepala di depan kamera oleh pasukan ISIS, dan masih banyak lagi.

Kemunculan ISIS yang mendeklarasikan berdirinya Khilafah Islam di Irak dan Suriah pada tahun 2013, disertai dengan pemberitaan masif di media mengenai aksi-aksi di luar perikemanusiaan yang mereka lakukan, memunculkan semacam image atau citra bahwa terorisme berakar dari ajaran agama, dalam hal ini Islam.

Dalam bahasa Inggris, to terrorize bermakna 'menakut-nakuti'. Dalam UU No. 15 Tahun 2003 Tentang Pemberantasan Tindak Pidana Terorisme Bab III dengan judul 'Tindak Pidana Terorisme', dicantumkan 2 pasal sebagai berikut yang secara umum memberikan gambaran mengenai apa saja perilaku yang masuk dalam kategori terorisme.

Pasal 6: Setiap orang yang dengan sengaja menggunakan kekerasan atau ancaman kekerasan menimbulkan suasana teror atau rasa takut terhadap orang secara meluas atau menimbulkan korban yang bersifat massal, dengan cara 
merampas kemerdekaan atau hilangnya nyawa dan harta benda orang lain, atau mengakibatkan kerusakan atau kehancuran terhadap obyek-obyek vital yang strategis atau lingkungan hidup atau fasilitas publik atau fasilitas internasional, dipidana dengan pidana mati atau penjara seumur hidup atau pidana penjara paling singkat 4 (empat) tahun dan paling lama 20 (dua puluh) tahun.

Pasal 7: Setiap orang yang dengan sengaja menggunakan kekerasan atau ancaman kekerasan bermaksud untuk menimbulkan suasana teror atau rasa takut terhadap orang secara meluas atau menimbulkan korban yang bersifat massal dengan cara merampas kemerdekaan atau hilangnya nyawa atau harta benda orang lain, atau untuk menimbulkan kerusakan atau kehancuran terhadap obyek-obyek vital yang strategis, atau lingkungan hidup, atau fasilitas publik, atau fasilitas internasional, dipidana dengan pidana penjara paling lama seumur hidup.

Di berbagai penjuru dunia, aksi-aksi terorisme dilakukan dari berbagai kalangan. Di Peru ada sebuah grup yang dikenal dengan nama Sendero Luminoso, di Columbia ada kelompok yang bernama Revolutionary Armed Forces of Colombia. Keduanya melakukan aksi-aksi teror (antara lain penculikan dan meminta uang tebusan) untuk menumbangkan pemerintah yang terpilih dalam pemilu. Namun tak dapat dipungkiri bahwa aksi-aksi teror yang mengatasnamakan agama memang dilakukan banyak kelompok, terutama yang beraksi di Timur Tengah.

Dalam artikel ini, penulis akan memfokuskan pembahasan menganai kelompokkelompok teror yang mengatasnamakan agama. Artikel ini akan berusaha menjawab pertanyaan, benarkah agama telah mendorong mereka untuk melancarkan aksi-aksi teror tersebut? Untuk menjawabnya, penulis akan menggunakan pemikiran seorang ahli perbandingan agama yang pernah bertugas di wilayah-wilayah konflik di Timur Tengah, yaitu Charles Kimball, yang tertuang dalam bukunya "When Religion Becomes Evil", dan diterjemahkan dalam bahasa Indonesia dengan judul "Kala Agama Jadi Bencana".

\section{Charles Kimball dan Pandangannya}

Charles Kimball lahir pada tahun 1950 dari sebuah keluarga imigran Yahudi. Dia menempuh pendidikan sarjana di Oklahoma University dan juga mengikuti pendidikan di The Southern Baptist Theological Seminary. Selain itu, ia mendapat gelar Ph.D. dari Harvard University dalam bidang perbandingan agama dengan spesialisasi Studi Islam. la kemudian menjadi profesor dan Direktur Program Studi 
Agama di University of Oklahoma. Selama masa studi doktoralnya di Harvard, ia merasakan atmosfer keberagaman yang luar biasa, karena berkumpul dengan orangorang yang mengambil program doktoral dari berbagai latarbelakang agama dan bangsa yang berbeda. Di tahun 1977-1978 ia pernah tinggal di Kairo dan melakukan perjalanan ke Mesir, Yordania, Suriah, Israel dan Palestina. Pada tahun 1983-1990 ia menjabat sebagai Direktur Urusan Timur Tengah di Dewan Gereja Nasional dan selama 30 tahun terakhir ia juga bekerja sama dengan Kongres dan Gedung Putih (Kimball, 2003:46).

Secara umum dalam situs pribadinya, Kimball dikenal sebagai pakar di bidang Timur Tengah, Islam, Hubungan Yahudi-Kristen-Muslim, serta hubungan agama dan politik di AS. la telah menulis lima buku, yang terbaru berjudul When Religion Becomes Lethal: The Explosive Mix of Politics and Religion in Judaism, Christianity, and Islam (2011). Sementara itu, bukunya yang menjadi pembahasan artikel ini, yaitu When Religion Becomes Evil (terbit pertama kali tahun 2002) dinobatkan sebagai 15 buku terbaik di bidang agama oleh Publishers Weekly dan telah diterjemahkan ke dalam berbagai bahasa, termasuk Indonesia.

Dalam buku When Religion Becomes Evil, Kimball tidak hanya membahas mengenai aksi terorisme yang terjadi di Dunia Islam namun juga pada agama-agama lain. Secara umum ia menyatakan bahwa pada dasarnya, agama bukanlah penyebab terjadinya terorisme. Namun ada lima tanda-tanda penting yang harus diwaspadai, ketika agama telah berubah menjadi paham yang mendorong terjadinya terorisme.

Sebelum menerangkan pandangannya tentang lima tanda penting itu, Kimball menjelaskan terlebih dahulu apakah benar agama membawa kerusakan setelah terjadinya banyak konflik atas nama agama. Menurut hasil observasi Kimball, agama bisa menjadi penyebab timbulnya konflik jika orang memandang secara ekslusif hanya agamanya yang benar dan agama yang lain salah. Argumen dari pernyataannya adalah bahwa sejarah kekristenan mengandung lebih banyak kekerasan dan kerusakan daripada agama lain. Kesombongan dalam memeluk agama ditambah dengan sikap merendahkan agama lain secara ironis membuat munculnya pernyataan bahwa agama adalah sebuah masalah.

Menurut Kimball, tendensi kaum beragama untuk melihat bahwa agama di luar agamanya memiliki cacat atau kekurangan terjadi dalam setiap agama. Untuk itu studi perbandingan agama membantu melihat agama dengan lebih jujur. Contohnya, sejarah gereja berkali-kali menunjukkan adanya kesenjangan antara contoh ideal yang diajarkan Yesus dengan cara orang Kristen hidup secara nyata 
dalam keseharian. Kimball mengutip pernyataan Gandhi yang mengeluhkan bahwa meskipun ia berteman dan didukung oleh pendeta Kristen yang berpikiran terbuka, namun ia melihat perilaku para penjajah (yang beragama Kristiani) di India dan Afrika Selatan bertentangan dengan ajaran Yesus. Menurutnya, tindakan berbicara lebih lantang daripada kalimat-kalimat. Gandhi pun mencari ajaran ideal Yesus yang hidup, yang kemudian ia temukan dalam tradisi Hindu. Martin Luther King Jr. juga berusaha untuk menghidupkan kata-kata dan pandangan Yesus, ia menemukan adanya kekuatan kehidupan dalam teladan Gandhi yang menghadapi sebagian umat Kristen yang mendukung diskriminasi ras dan melawan hak asasi rakyat (Kimball, 2003:35).

Atas dasar itulah, sebagian pihak berpendapat bahwa agama tidak menjadi sumber konflik karena yang menjadi masalah adalah penganut agamanya yang tidak sesuai dengan ajarannya. Untuk agama Islam, hanya dengan mempelajari halhal mendasar dari berbagai aliran, tulisan, dan praktik spiritual yang dilakukan umat Muslim selama 1400 tahun terakhir, kita bisa mengetahui bahwa Taliban bukanlah representasi Islam yang utuh. Begitu pula, berbagai keragaman tradisi mistik Yahudi atau Yahudi-reformis kontemporer di Amerika Serikat menunjukkan bahwa tradisi agama jauh lebih fleksibel dari kesan kaku yang selama ini tampak. Untuk itu, Kimball menekankan bahwa sangat penting memahami agama sebagai suatu hal yang kompleks dan komponen penting dalam kehidupan manusia, sebagaimana pendekatan yang dilakukan oleh Joseph Campbell, Huston Smith, Willfred Cantwell Smith dan yang lain (Kimball, 2003:39).

Kimball mengutip analogi yang banyak dikemukakan oleh pihak yang berpendapat bahwa agama adalah sumber terorisme, "agama bagaikan senapan dengan peluru". Di tangan Osama bin Laden, peluru itu ditembakkan dan membunuh orang. Di tangan Mahatma Gandhi, yang terjadi adalah sebaliknya. Dengan kata lain, jika di dalam suatu agama tidak ada fleksibilitas, kesempatan untuk berkembang, dan sistem evaluasi dalam institusi dan ajaran agama, agama sangat berpotensi menjadi bagian utama masalah. Kimball menyimpulkan, apakah agama menjadi sumber masalah atau tidak akan kembali pada bagaimana seseorang memahami agamanya. Di dalam jantung orientasi dan pencarian keagamaan, manusia dapat menemukan makna dan harapan. Dalam bentuk asli dan inti ajarannya, agama adalah mulia. Namun bagaimana agama berkembang, hampir selalu menjadi kurang ideal. Para penganut agama sering mengkultuskan pemimpin agama, doktrin, dan keinginan untuk mempertahankan struktur institusional sebagai justifikasi bagi perilakuperilaku yang jauh dari nilai ideal agama (Kimball, 2003:40). 
Sebagai contoh dari perilaku yang membawa agama sebagai justifikasi atas aksi-aksi kekerasan adalah pernyataan Presiden AS, George W. Bush segera setelah terjadinya teror peledakan gedung WTC tanggal 9 Septemberi 2001 (Teror 9/11). Dalam pidatonya, Bush menyatakan bahwa 'perang melawan terorisme' adalah 'perang salib'. Mengomentari hal ini, Kimball menilai bahwa tidak diragukan lagi Presiden Bush telah membawa keyakinan agamanya dalam proses pembuatan keputusan negara. Bush tidak berkhutbah, namun pendapat keagamaannya menjadi bukti. Bush menggunakan perumpamaan kekuatan agama seperti konfrontasi antara yang "baik dan jahat". Rakyat dan negara menjadi harus memilih, tidak ada kenetralan. "Kamu harus bersekutu dengan kebaikan dan memusnahkan kejahatan atau akan dihitung sebagai musuh dalam perang melawan terorisme," demikian retorika yang dipakai Bush. Ketika Bush menyandingkan 'jahat' dan 'baik', ia membahasakan sebuah rujukan yang lazim dalam dualisme kosmik. Realitas kejahatan setidaknya sama tuanya dengan kesadaran manusia (Kimball, 2003:44).

Di saat yang sama, retorika serupa juga dapat ditemukan dalam pernyataan Osama bin Laden. Pasca Teror 9/11, sebagai pimpinan Al-Qaeda, bin Laden mengatakan bahwa "Tuhan Yang Maha Kuasa telah menghantam Amerika Serikat dan menghancurkan bangunan-bangunannya yang paling baik". Bin Laden juga berterima kasih kepada Tuhan atas kematian dan kehancuran yang diakibatkan oleh tindakan anggota Al-Qaeda (Naharong, 2013).

Menanggapi pertanyaan apakah agama adalah sumber konflik atau bukan, Kimball terlihat condong pada pendapat yang kedua, yaitu agama bukan menjadi sumber konflik karena perilaku teror yang ditunjukkan oleh penganutnya adalah gambaran institusi manusia yang telah menyelewengkan doktrin agama. Apapun yang dikatakan seseorang beragama tentang cintanya kepada Tuhan atau tugasnya dalam beragama, ketika perilaku orang tersebut terhadap orang lain penuh kekerasan dan merusak dan menyebabkan penderitaan di tengah tetangganya, artinya agama telah dikorupsi dan karena itu diperlukan reformasi dalam paham keberagamaannya.

Untuk itulah, Kimball berpendapat bahwa tantangan bagi para akademisi zaman kini adalah kemampuan melihat konflik dalam perspektif yang lebih global, sebagaimana yang ia lakukan dengan pendekatan perbandingan agama yang dapat mengerti keragaman namun tetap memahami hakikat sebenarnya agama. Di sisi lain, Kimball menyatakan bahwa kita harus melihat permasalahan ini secara pragmatis agar dapat memberikan solusi. Untuk itulah pendeteksian terhadap lima 
tanda berikut ini menjadi sangat penting agar para peneliti dan akademi mampu mendiagnosa dan menguraikan permasalahan yang sebenarnya.

\section{Lima Tanda Peringatan Dini dari Kimball}

Berikut ini kelima tanda yang diidentifikasi oleh Kimball, tanda-tanda yang menunjukkan bahwa sebuah pemahaman agama telah bergeser dan harus segera diantisipasi.

\section{Klaim Kebenaran Mutlak}

Klaim kebenaran dalam sebuah agama adalah satu hal yang memang telah menjadi asas bagi sebuah agama dan hal ini lumrah adanya, namun akan menjadi sebuah bahaya jika penganutnya memutlakkan kebenaran yang dimiliki masingmasing agama dan memandang bahwa keyakinan selain yang mereka anut adalah sesat atau salah. Prinsip hitam-putih dalam melihat kenyataan dunia yang beragam bukan sikap yang bijak dan menurut Kimball, ini akan menjadi cikal bakal tindakan ekstremis dalam bentuk terorisme. Salah satu bentuk dari klaim kebenaran mutlak ini biasanya ditimbulkan oleh penyalahgunaan teks suci. Sikap fatal ini bahkan ditegaskan Kimball dengan mengutip kalimat Shakesphare "bahkan iblis pun dapat mengutip ayat demi mencapai segala tujuannya".

Sebuah penafsiran yang terlalu tekstual atas sebuah ayat dapat mengantarkan umatnya pada sebuah tujuan semu dengan cara destruktif. Di satu sisi, klaim kebenaran adalah esensi penting agama, namun di saat yang sama, inilah titik dimana perbedaan penafsiran muncul, dengan konsekuensi yang berpotensi merusak, orang mengira mengenal Tuhan, menyalahgunakan teks-teks suci dan menyebarkan versi kebenaran absolut mereka yang khas. Selain itu, ketiadaan kata sepakat dalam menafsirkan klaim kebenaran juga menghasilkan fragmentasi atau perpecahan di dalam internal agama. Hal ini terjadi baik dalam Islam maupun agama-agama lainnya. Misalnya, Kimball menuliskan bahwa Kristen yang awalnya (dua ribu tahun yang lalu) adalah sebuah agama yang sederhana sekarang telah ada menjelma dalam bentuk ribuan gereja dan denominasi.

Di dalam agama Budha, kerusakan yang timbul akibat klaim kebenaran mutlak pernah terjadi pada sekolah Nichiren Buddhisme di Jepang. Nichiren adalah pendiri sekolah tersebut. la merasa tertekan dengan berkembangnya teks, ajaran dan praktik Buddha di Jepang pada abad ke 13. Dia meyakini satu-satunya teks yang suci hanyalah Saddharma Pundarika Sutra. la memandang di luar dari itu adalah pelanggar. Dengan mengutip pernyataan Buddha, Nichiren menyatakan bahwa 
orang yang membunuh orang akan jatuh ke dalam alam neraka, hantu kelaparan atau hewan kecuali dalam kasus fitnah Dharma. Pernyataan Buddha ini ia gunakan untuk justifikasi bahwa membunuh para pelanggar (orang di luar sektenya) tidak akan mendapatkan hukum karma. Ajaran tersebut hidup kembali dalam dasar satu agama yang berpengaruh, Soka Gakkai.

Dalam bukunya, Kimball mengutip ayat Al Qur'an surah Al Baqarah ayat 190191, "dan perangilah di jalan Allah orang-orang yang memerangi kamu, tetapi jangan melampaui batas. Sungguh, Allah tidak menyukai orang-orang yang melampaui batas. Dan bunuhlah mereka dimana kamu temui mereka dan usirlah mereka dari mana mereka telah mengusir kamu. Dan fitnah itu lebih kejam daripada pembunuhan. Dan janganlah kamu perangi mereka di Masjidil Haram kecuali jika mereka memerangi kamu di tempat itu. Jika mereka memerangi kamu, maka perangilah mereka. Demikianlah balasan bagi orang kafir" (Kemenag, 2014:29). Ayat ini digunakan Osama bin Laden sebagai argumen justifikasi atas aksi teror yang dilakukan Al Qaida terhadap orang-orang yang di luar kelompoknya dan di luar Islam. Klaim yang didasarkan pada penafsirannya yang dangkal terhadap ayat Al Quran juga digunakan untuk merekrut milisi dari kalangan orang-orang yang miskin. Mereka diiming-imingi kenikmatan surgawi sebagai ganjaran bagi aksi jihad, sebagaimana yang diterangkan dalam ayat tersebut (Kimball, 2003:104).

\section{Kepatuhan Buta}

Agama otentik melibatkan intelektualitas saat orang bergumul dengan misteri keberadaan dan tantangan hidup di dunia ini yang tidak sempurna. Sebaliknya ketaatan buta adalah tanda pasti dari agama yang korup. Maka perlu diwaspadai gerakan keagamaan manapun yang berusaha membatasi kebebasan intelektual dan integritas individu para penganutnya. Bila orang melepaskan tanggung jawab pribadi dan menyerah pada otoritas seorang pemimpin karismatik atau menjadi diperbudak oleh gagasan atau ajaran tertentu, maka agama dapat dengan mudah menjadi kerangka kerja untuk kekerasan dan penghancuran.

Seperti contohnya pada kasus, James Warren Jones. Jones lahir di Indiana pada masa terjadinya puncak depresi masyarakat di tahun 1931. Jones memulai pelayanan gereja di tahun 1954, ideologinya sangat dipengaruhi oleh pantekostalisme dan idealisme sosialis yang berakar pada sosialis komunis. Di tahun 1955 ia membentuk gereja injil People Temple yang berkomitmen pada kesetaraan rasial dan keadilan sosial. Jones bersama dengan pengikutnya kerap berpindah tempat karena 
terkadang ideologi mereka yang bertentangan dengan masyarakat umumnya dan ada anggapan bahwa Jones telah memisahkan diri dari versi awal kekristenan alkitab. Namun bagi pengikutnya, Jones adalah seorang figur karismatik dan pesan keadilan serta sosial ekonominya menyentuh hati dan pikiran mereka. Hingga pada puncaknya di tahun 1978 Jones memerintahkan pengikutnya meminum racun sianida agar mempercepat kehidupan didunia untuk segera menuju surga, hingga akhirnya diberitakan ada 909 orang yang tewas akibat dari racun tersebut.

Kimball berpendapat bahwa "Ketika pemimpin agama memiliki kekuasaan besar terhadap para pengikutnya, selalu ada potensi bahaya. Ketika mereka menginstruksikan pengikutnya utuk melakukan aksi kekerasan dan pengikutnya mematuhi tanpa kritik, kemungkinan penyalahgunaan kekuasaan akan sangat besar."

Dalam kasus Timur Tengah, Kimball mencontohkan Ayatullah Khomeini. Kimball menceritakan bahwa ia pernah berkunjung ke Iran dan bertemu langsung dengan Ayatullah Khomeini. Saat itu, dia dan beberapa pemuka agama lain diutus pemerintah AS untuk bernegosiasi dalam kasus warga AS yang disandera para mahasiswa Iran (1979). Kimball mengakui kharisma Ayatullah Khomeini dan mendeskripsikan, “... berbicara lembut dan bersikap kebapakan. Meskipun ia berusia 80 tahun saya melihatnya sangat karismatik, matanya sangat hidup dan komunikatif" (Kimball, 2003:94-95).

Namun kemudian Kimball menyatakan bahwa fatwa Ayatullah Khomeini agar para pemuda Iran berperang melawan Irak (1980-1987) telah menyebabkan ribuan pemuda tewas. Begitu pula, akibat fatwa para ulama Syiah di Lebanon, banyak anak muda yang tewas dalam aksi-aksi bom bunuh diri. Kemudian Kimball mencoba menerangkan bahwa akibat fatwa tersebut, situasi menjadi kacau.

Di sini, analisis Kimball tentang fatwa Khomeini atau ulama Lebanon yang telah menyebabkan tindakan kekerasan tersebut seolah-olah telah menyejajarkan tindakan yang diambil oleh Khomeini dengan Jim Jones. Padahal konteks terjadinya tindakan tersebut jelas berbeda. Dalam perang Iran-Irak dan perang melawan Israel di Lebanon, konteksnya adalah invasi milter Irak ke Iran; dan invasi militer Israel ke wilayah sebuah negara berdaulat (Iran dan Lebanon). Di sini, kekerasan yang terjadi adalah perlawanan yang dilakukan oleh penduduk di Iran dan Lebanon terhadap invasi militer asing. Dalam dua kasus ini, fatwa yang dikeluarkan oleh ulama Iran dan Lebanon merupakan seruan agar rakyatnya rela berkorban demi menentang penjajahan, bukan sebaliknya. 


\section{Membangun Zaman Ideal}

Dalam setiap agama, ada impian mengenai 'zaman ideal' dimana keadilan dan kedamaian akan terwujud. Kimball membuka penjelasan mengenai 'zaman ideal' ini dengan kisah Yehuda Etzion, seorang ekstrimis Yahudi yang ditangkap sedang membawa sejumlah bahan peledak pada tanggal 26 Januari 1984. Etzion hendak meledakkan Masjidil Aqsha karena meyakini bahwa dengan cara itulah tempat suci Yahudi (Temple Mount) bisa kembali ditegakkan.

Yehuda Etzion kemudian memberikan pengakuan bahwa ia memandang pentingnya pemurnian wilayah yang diklaim sebagai tempat berdirinya "Temple Mount" dari kekuasaan orang-orang Islam. Usaha 'pemurnian' ini tidak hanya terjadi sekali itu, melainkan telah terjadi selama belasan kali dan menjatuhkan korban di kalangan Muslim. Agenda'pemurnian' ini terkait dengan harapan yang diinterpretasi dari ayat-ayat Alkitab yang terkait dengan kedatangan 'juru selamat' (Messiah). Mereka percaya akan datangnya sang Mesiah di akhir zaman untuk memimpin mereka dalam pertempuran Armageddon.

Keyakinan yang sama juga dimiliki oleh penganut Protestan yang meyakini bahwa berdirinya kembali Temple Mount akan menjadi sebab bagi kemunculan Yesus kedua kalinya dan menjadi awal bagi masa damai seribu tahun (Kimball, 2003:110-111).

Impian terhadap zaman ideal versi Yahudi dan Protestan ini telah mendorong didirikannya negara Israel dan hal ini kemudian memunculkan reaksi dari warga Arab Palestina dan negara-negara Arab di sekitarnya. Akibatnya, peperangan di Timur Tengah terus berlangsung hingga kini.

Israel telah berdiri lewat Resolusi Dewan Keamanan PBB No. 181 tahun 1947. Pendirian negara Israel ini telah memberikan dampak yang luar biasa. semenjak di tahun pertama ia mendirikan negara. Beberapa kerusakan serta daftar kekerasan yang mereka buat terangkum dengan jelas dalam berbagai pemberitaan. Misalnya, selama 2014, menurut OCHA (Office for the Coordination of Humanitarian Affairs), Israel dan HAMAS bertempur dalam peperangan dahsyat di Gaza yang membunuh hampir 2.200 orang sementara kekerasan intens di Yerussalem timur dan tepi barat membunuh puluhan warga Palestina dan hanya beberapa warga Israel (Antara News, 2015).

Menurut laporan OCHA yang berjudul "Fragmented Lives" di jalur Gaza, 1,8 juta warga Palestina menghadapi peningkatan permusuhan paling buruk sejak 1967 


\section{Pendapat Kaum Muslim AS tentang Aksi Terorisme}

\begin{tabular}{|l|c|c|c|}
\hline \multicolumn{4}{|c|}{$\begin{array}{c}\text { Pertanyaan: } \\
\text { apakah Anda merasa bahwa kekerasan terhadap warga sipil demi mencapai } \\
\text { tujuan }\end{array}$} \\
\cline { 2 - 4 } & $\begin{array}{c}\text { sering/terkadang bisa } \\
\text { dijustifikasi }\end{array}$ & $\begin{array}{c}\text { jarang/tidak pernah } \\
\text { bisa dijustifikasi }\end{array}$ & $\begin{array}{c}\text { Tidak } \\
\text { tahu }\end{array}$ \\
\cline { 2 - 4 } & $\%$ & $\%$ & $\%$ \\
\hline Kaum Muslim AS & 12 & 84 & 4 \\
\hline Laki-laki & 11 & 82 & 7 \\
\hline Perempuan & 12 & 85 & 3 \\
\hline Usia 18-39 & 14 & 79 & 7 \\
\hline Usia di atas 40 & 8 & 90 & 7 \\
\hline Pendidikan SMA & 16 & 77 & 5 \\
\hline Pernah kuliah & 11 & 84 & 1 \\
\hline Lulusan PT & 7 & 92 & 1 \\
\hline Lahir di AS & 10 & 89 & 7 \\
\hline Kelahiran luar AS & 12 & 81 & 3 \\
\hline Partai Republik & 19 & 78 & 3 \\
\hline Partai Demokrat & 9 & 88 & 5 \\
\hline Religius & 12 & 84 & 3 \\
\hline Tidak religius & 11 & 83 & \\
\hline Warga Umum AS & 14 & & 2 \\
\hline
\end{tabular}

Tabel diadaptasi dari Pew Research Center (2017)

dengan lebih dari 1.500 warga sipil terbunuh, lebih dari 11.000 orang terluka dan 100.000 orang terlantar. Israel juga terus merampas wilayah-wilayah penduduk Palestina di Tepi Barat, Jalur Gaza, dan wilayah Arab di Yerussalem Timur. PBB berupaya menyelesaikan konflik ini dengan merilis Resolusi 2334 Dewan Keamanan PBB, yang menuntut Israel untuk segera dan sepenuhnya menghentikan semua kegiatan pemukiman di wilayah pendudukan Palestina, termasuk Yerussalem Timur. Namun Israel melanggarnya dengan tetap melanjutkan pembangunan pemukiman Yahudi di wilayah Palestina yang didudukinya (Antara News, 2015).

Pelanggaran Israel ini terlihat dalam jumlah rumah yang dibangun di pemukiman ilegal mengalami peningkatan dua kali lipat, contohnya di area CTepi Barat dari 3.000 unit pada 2016 menjadi hampir 7.000 unit di 2017, di Yerussalem hal serupa terjadi, dari 1.600 unit menjadi 3.100 unit (Antara News, 2017). 
Pendirian negara Israel (yang berlanjut dengan perampasan tanah dan rumah milik warga Arab Palestina) bukan hanya memberikan kerugian kepada orangorang Palestina yang beragama Islam. Menurut Pastor Mitri Raheb yang berkiprah di Palestina, ada sekitar 180.000 penganut Kristen di Palestina dan mereka turut menentang perang-perang yang terjadi. Selain itu, dalam Yahudi sendiri terdapat kelompok orang Yahudi ortodoks yang menolak Zionisme dan pendirian negara Israel. Di antaranya, para Rabi yang bergabung dalam organisasi bernama Neturei Karta. Mereka percaya bahwa Israel sejati hanya dapat dibangun kembali dengan kedatangan Mesiah (Jewish Virtual Library, 2017). Kedua penganut agama, baik Yahudi dan Kristen tidak menginginkan adanya konflik-konflik yang terjadi atas dasar pendirian negara Israel. Sehingga tepat yang dikatakan Kimball bahwa mereka yang tergabung dalam kelompok ekstrim tersebut telah mengabaikan ayat Tuhan yang lain sebagaimana yang termaktub dalam Matius 5:9, "Berbahagialah orang yang membawa damai, karena mereka akan disebut anak-anak Allah".

Sementara itu, sebagian kalangan Islam memimpikan sebuah pemerintahan Islami, antara lain yang 'diperjuangkan' oleh AI Qaida dan ISIS. Menurut Kimball, pemerintahan Islam versi Taliban (kelompok Islam ekstrim di Afghanistan) membahayakan penduduk di negara tersebut dan komunitas dunia secara umum. Taliban telah memaksakan hukum Islam versinya sendiri yang sangat rigid dan ekstrim. Taliban juga memberikan perlindungan kepada kelompok teroris AI Qaida pimpinan Osama bin Laden. Taliban adalah contoh nyata dari (pemahaman) 'agama yang menjadi bencana'. Al Qaida menginginkan berdirinya pemerintahan Islam di berbagai negara-negara mayoritas Muslim. Sangat jelas bahwa mayoritas kaum Muslimin di berbagai negara menolak Islam versi Taliban-AI Qaida dan memandang mereka sebagai kelompok ekstrim (Kimball, 2003:171).

Penolakan mayoritas kaum Muslimin tersebut dikarenakan mereka menyadari besarnya bahaya dan dampak buruk yang dibawa oleh kelompok ekstrim ini. Dampak buruk ini ini terekam dalam sejarah tindakan pengrusakan yang terjadi di beberapa negara diantaranya di Kenya dan Tanzania yang menewaskan lebih dari 200 orang dengan sebagian besar korbannya adalah penduduk setempat, serangan lain yang paling menyedot perhatian publik dan media yaitu penyerangan WTC, Pentagon, dan gedung parlemen AS, selain itu termasuk juga peristiwa bom bunuh diri di Yaman dan Suriah.

Menurut Kimball, banyak orang di Barat yang bertanya-tanya mengapa Al Qaida sedemikian membenci Barat. Kimball memberikan penjelasan dengan merunut kembali kepada sejarah peradaban Islam. Sejarah Islam yang gemilang mencatatkan 
banyak kemajuan di berbagai bidang, seperti matematika, kimia, kedokteran, filsafat, navigasi, arsitektur, holtikultura dan astronomi. Kemajuan ini menjadi satu kebanggaan tersendiri bagi umat Islam. Namun masa kegemilangan ini seketika berakhir di abad 16 hingga 20, ketika sebagian besar wilayah dengan penduduk Muslim dikuasai oleh imperium Barat.

Dari pendudukan asing ini, banyak umat Muslim masih berharap agar ada jalan bagi kehidupan yang lebih baik bagi mereka. Salah satu usaha yang dijalankan yaitu terlihat dalam terbentuknya sejumlah negara baru. Pada era pascakolonial, banyak Muslim memimpikan dan berusaha merevitalisasi bentuk masyarakat Islam terkini, namun mereka akhirnya merasa frustasi karena selalu mendapati kegagalan. Di banyak negara-negara berpenduduk maoritas Islam, mereka merasa sistem politik, ekonomi, dan sosial telah gagal untuk memecahkan kebuntuan yang ada, di sisi lain terdapat segelintir orang yang berkuasa yang merasakan kekayaan luarbiasa yang bekerja sama dengan kekuatan ekonomi Barat.

Keadaan ini dimanfaatkan oleh sebagian kelompok-kelompok Islam, salah satunya Al-Qaeda untuk membangkitkan perlawanan melawan musuh yaitu Barat dan pemerintah domestik yang bersekutu dengan pihak Barat. Sebagai sebuah neofundamentalisme yang dihasilkan oleh Perang Dingin, fundamentalisme kontemporer merupakan proyek politik modern dan bukan sisa-sisa kebudayaan tradisional (Hamdani, 2006:251).

Sebagaimana yang dinyatakan Karen Armstrong dalam bukunya yang telah diterjemahkan dengan judul "Berperang Demi Tuhan", terkait dengan aksi AlQaeda saat menyerang gedung WTC ditanggal 11 September, bahwa Mohamed Atta, pembajak Mesir yang mengemudikan pesawat terbang, adalah seorang yang pecandu alkohol dan meminum Vodka sebelum menaiki pesawat tersebut, dan pembajak lainnya termasuk penikmat klab dan para wanita Las Vegas. Kemunculan fundamentalisme sebagaimana yang disampaikan oleh Mahmood Hamdani merupakan sebuah warisan kolonialisme yang sangat dipengaruhi oleh faktor ekonomi dan politik, dan pernyataan Armstrong semakin menguatkan bahwa kelompok Al-Qaeda jelas tidak mencerminkan nilai-nilai keislaman terutama para eksekutor pembajak yang sering dianggap sebagai mujahid.

Persepsi masyarakat Muslim AS pun menunjukkan bahwa mayoritas mereka tidak menyetujui aksi kekerasan dalam mencapai tujuan politik. Dalam survey yang dilakukan oleh Pew Research Center tahun 2017, ditemukan bahwa 84\% Muslim AS berpendapat, kekerasan atas nama agama tidak pernah bisa dijustifikasi. Pandangan 
ini dimiliki oleh Muslim yang menyatakan bahwa agama penting bagi kehidupan mereka dan Muslim yang menyatakan bahwa agama tidak terlalu penting bagi kehidupan mereka.

\section{Tujuan Menghalalkan Segala Cara}

Dalam agama yang otentik dan hakiki, tujuan dan cara untuk mencapai tujuan akan selalu koheren. Tujuan dari agama adalah kebaikan, karena itu, cara untuk mencapaikan haruslah berupa cara-cara kebaikan pula. Namun, menurut Kimball, banyak penganut agama yang kehilangan fokus sehingga hanya memikirkan bagaimana cara mencapai tujuan. Ketika ada hal-hal kunci dalam agama (key feature of religion) yang tercederai, atau ingin dicapai, sebagian penganut agama berusaha mencapainya dengan menghalalkan segala cara. Mereka menjelma menjadi pemilik klaim kebenaran tunggal dan fanatik buta demi mencapai tujuan-tujuan itu, dan hal ini amat membahayakan umat manusia secara global.

Ada beberapa key features (hal-hal kunci) yang diidentifikasi oleh Kimball, yang berpotensi membuat penganut agama menghalalkan segara cara. Berikut ini tiga di antaranya.

\section{(1) Mempertahankan tempat-tempat suci}

Semua tradisi keagamaan membedakan antara yang suci dan yang profan. Ruang, waktu, objek, dan orang-orang dipisahkan dan diikat secara berbeda berdasarkan peran mereka dalam kisah-kisah suci di setiap tradisi. Ruang (tempat) suci merupakan komponen kunci kehidupan dan praktik keagamaan. Mereka yang tergabung dalam satu komunitas agama cenderung untuk mempertahankan ruangruang suci ini.

Di Palestina/Israel, ada dua tempat suci yang dijadikan contoh dalam pembahasan Kimball, yaitu the Cave of the Patriarchs dan masjid Ibrahim. Keduanya dianggap sebagai tempat suci oleh 3 agama, Muslim, Yahudi, dan Kristen. Selama enam puluh tahun terakhir, konflik terjadi silih berganti di sana. Pada tanggal 25 Februari 1994 tempat suci menjadi tempat pembunuhan massal. Saat itu bertepatan dengan hari libur orang Yahudi, Purim, untuk memperingati pembebasan orang Yahudi dari upaya pemusnahan yang dilakukan penindas mereka. Ketika ratusan Muslim Palestina, laki-laki dewasa dan anak-anak berkumpul untuk melaksanakan Shalat di Masjid, Baruch Goldstein, seorang dokter Amerika yang tinggal di pemukiman Yahudi Kiryat Arba, masuk ke masjid dengan menyamar sebagai tentara Israel. la menembak 
dengan senapan mesin, sehingga menewaskan 29 orang dan melukai banyak orang sebelum ia dibunuh oleh orang yang ingin dia bunuh (Kimball, 2003:202).

Pemukiman Kiryat Arba, tempat dimana Goldstein tinggal, persis berada di tengah-tengah mayoritas warga Palestina, karena di sekitarnya ada tempat-tempat suci yang diasosiasikan dengan Ibrahim dan orang-orang suci. Goldstein adalah pengikut setia Rabi Meir Kahane. Goldstein menganggap Israel (termasuk Yudea dan Sumeria) sebagai tempat suci bagi Yahudi. Secara terbuka, ia mendukung pengusiran warga Palestina dari wilayah ini. la mengabdikan hidupnya demi tujuan ini, suatu tujuan yang menempuh segala cara, termasuk membunuh warga Muslim ketika mereka shalat berjamaah di atas nisan pendahulu kedua belah pihak (Kimball, 2003:203).

\section{(2) Memperkuat Identitas Kelompok Melawan Orang Luar}

Contoh dari tindakan memperkuat identitas kelompok melawan orang luar adalah Holocaust, sebuah pemusnahan sistematis terhadap lebih dari 6 juta orang Yahudi pada masa pemerintahan Nazi Hitler Jerman. Kebijakan-kebijakan Nazi Jerman bukanlah kebijakan resmi Kristen, melainkan merupakan produk sejarah panjang dan tercela perilaku orang Kristen terhadap orang Yahudi dengan mengutip dari satu ayat yang bermakna bahwa Tuhan telah dicampakkan oleh orang-orang Yahudi (Romawi 9-11). Banyak orang Kristen mengutip teks ini selama berabadabad sebagai dasar untuk mengambinghitamkan Yahudi sebagai sebuah kelompok. Seperti dibicarakan sebelumnya, klaim kebenaran mutlak yang didasarkan atas pembacaan teks suci yang sepotong-sepotong sering menjadi tanda agama yang korup.

Sosiolog agama, Rodney Stark membuat katalog tentang puluhan ledakan anti Semit yang dilakukan secara kolektif di Jerman, Perancis, Inggris, dan Spanyol yang menimbulkan puluhan ribu kematian yang tercatat selama abad pertengahan. Pola serupa kini terus berlangsung dalam pelbagai manifestasi selama berabad-abad. Banyak orang Kristen di Barat umumnya berpandangan bahwa orang-orang Yahudi membahayakan identitas Kristen (Kimball, 2003:210).

\section{(3) Memperkuat Identitas Kelompok Dari Dalam}

Banyak praktik keagamaan yang menindas atau mendiskriminasi para penganut agama itu sendiri, terutama kaum perempuan. Dalam Islam, ada beberapa praktik yang dianggap mendiskriminasi perempuan. Namun, menurut Kimball, penafsiran atas teks suci sangatlah beragam. Banyak penafsir yang menekankan bahwa dalam 
Islam perempuan dan laki-laki adalah setara di hadapan Tuhan, meskipun memiliki peran dan tanggung jawab berbeda. Namun implementasinya bervariasi di berbagai negara Muslim. Kimball mencontohkan, di Tunisia, di mana 98\% penduduknya adalah Muslim, kaum perempuan mendapatkan pendidikan yang baik dan hak untuk memilih dalam pemilu. Di Arab Saudi, kondisi sebaliknya terjadi, perempuan sangat banyak dibatasi. Di Iran, pasca Revolusi Islam, perempuan bebas mengikuti pemilu dan mereka duduk di parlemen.

Menurut Kimball, poinnya adalah dalam agama ada cara yang sah untuk mengubah aturan-aturan 'relijius'. Apalagi, banyak hal yang dipersepsi sebagai aturan relijius sebenarnya adalah tradisi. Misalnya, aturan sunat terhadap perempuan sebenarnya adalah tradisi Afrika jauh sebelum mereka mengenal ajaran Kristen atau Islam (Kimball, 2003:215).

\section{Menyerukan Perang Suci}

Istilah 'perang suci' awalnya tertuju pada perang yang terjadi selama satu abad antara Islam dan Kristen (Perang Salib). Dalam 'perang suci', agama digunakan untuk mensakralkan peperangan. Menurut Kimball, mendeklarasikan perang sebagai sesuatu yang'suci' adalah tanda bahwa sebuah pemahaman agama telah terkorupsi. Dalam pandangan Kimball, intisari agama yang otentik adalah ditemukannya perdamaian dan kedamaian batin bagi penganutnya serta koeksistensi antara manusia dengan seluruh makhluk lainnya.

Meskipun Kimball juga mengakui bahwa ada situasi-situasi yang membahayakan yang memang memerlukan penggunaan kekuatan atau tindakan militer namun ia menolak bila agama digunakan sebagai justifikasi bagi perang tersebut (Kimball, 2003:237).

Dalam pembahasan ini Kimball memberikan contoh dari dua sisi, Kristen dan Islam. Dalam Perang Teluk yang dimulai 16 Januari 1991 dengan bombardir pesawat tempur AS ke Irak dan Kuwait (untuk mengusir keluar tentara Irak yang menganeksasi Kuwait). Menurut Kimball, Perang Teluk tidaklah didasarkan pada agama. Namun, pemerintah AS saat itu menggunakan framing relijius untuk menggalang dukungan rakyat. Sejak awal, Presiden H.W. Bush selalu menggunakan retorika relijus. Misalnya, ketika ia mengumumkan rencana pengiriman tentara AS ke Teluk, ia menutup pidatonya dengan kalimat, "Saya meminta seluruh gereja untuk mendoakan semua pihak yang melindungi kepentingan AS. Menegakkan prinsip-prinsip kira adalah tradisi AS. ...semoga Tuhan memberkati AS." Kemudian, gereja-gereja dimobilisasi 
untuk memenuhi harapan Presiden Bush (Kimball, 2003:249). Namun, tindakan ini dikecam oleh banyak kalangan Kristiani AS dan mereka menyatakan bahwa'perang bukanlah jawaban' (Kimball, 2003:254).

Sementara itu, dalam Islam, istilah 'perang suci' identik dengan kata 'jihad'. Kimball menjelaskan panjang lebar, dengan mengutip berbagai referensi dari pemikir-pemikir Islam, mengenai makna 'jihad' yang hakiki. Antara lain, Kimball menulis bahwa meskipun dalam Al Quran ada ayat yang menyerukan agar kaum Muslimin berjuang melawan pihak-pihak yang menyerang Islam, namun ada pula ayat yang menyerukan perdamaian, misalnya QS 8:61, "tetapi Jika mereka condong kepada perdamaian, maka terimalah dan bertakwallah kepada Allah. Sungguh dia Maha Mendengar, Maha Mengetahui" (Kemenag, 2014:184).

Kimball mengutip pernyataan Zayed Yasin, pakar rekayasa biomedis dan mantan Presiden Harvard Islamic Society, "Jihad dalam tradisi Muslim menggambarkan suatu perjuangan untuk melakukan kebajikan. Ini sama sekali bukan pidato tentang jihad dalam pengertian perang, atau jihad 11 September, atau Israel dan Palestina, atau politik. Saya ingin menggunakan ide perjuangan untuk manyatakan bahwa kita, sebagai lulusan Harvard, yang telah diberi rahmat yang luar biasa, memiliki tugas dan tanggung jawab kepada dunia untuk berjuang melawan ketidakadilan, dan berjuang demi keadilan sosial" (Kimball, 2003:260).

Kimball juga menjelaskan Islam sebagai agama yang mengajarkan kedamaian, tidak seperti selama ini yang dilihat oleh kacamata media Barat. Salah satu bentuk ajarannya yang damai dapat dilihat dalam praktik kaum Muslimin yang setiap memulai aktivitasnya selalu menyebut nama 'Allah yang Maha Pengasih dan Penyayang. Kimball juga memperlihatkan ayat-ayat Al-Qur'an yang memberikan pandangan yang lebih simpatik terhadap agama lain.

Cendekiawan Muslim, Haidar Bagir, dalam bukunya "Islam Tuhan Islam Manusia" menjelaskan bahwa Tuhan dalam ajaran Islam adalah Tuhan yang penuh kasih sayang. Bagir menulis, "Pada kenyataannya, bukan saja Tuhannya Islam adalah Tuhan Kasih-sayang yang menyatakan bahwa 'Kasih-sayang-Ku meliputi apa saja ... dan menundukkan murka-Ku' (Bagir, 2017: 232). Dalam Al Quran, semua surat (kecuali Al Taubah) diawali dengan kalimat kasih sayang, yaitu bismillaahirrahmaanirrahiim, yang berarti'dengan nama Allah yang Maha Pengasih Lagi Maha Penyayang'. Menurut Bagir, makna arrahman dan arrahim adalah 'yang menyayangi seluruh makhluk-Nya tanpa terkecuali dengan memberinya semua bekal yang memungkinkannya hidup berbahagia, dan pada saat yang sama memberikan kasih-sayang khusus berupa 
petunjuk kepada manusia yang mau menapaki jalan-Nya'. Bagir juga mengutip hadis Nabi, “Cinta adalah asas (ajaran agama)-ku." (Bagir, 2017:232).

Kimball mengkritisi media Barat yang memfokuskan pada minoritas kecil dalam tubuh Islam yang menafsirkan kata 'jihad' secara sempit, seperti aksi-aksi Al Qaida. Bahkan Perdana Menteri Inggris, Margaret Thatcher, pasca Teror 9/11 mengeluarkan kecaman kepada umat Muslim yang dianggapnya diam saja atas serangan tersebut. Opini tentang 'diamnya umat Muslim' ini juga disebarluaskan di media-media AS selama dekade awal abad ke-21. Pernyataan para pemimpin Muslim terhadap aksi teror itu tidak banyak mendapatkan liputan. Bahkan pertemuan para ulama besar Islam di Amman, Jordania, tahun 2005 tidak banyak diketahui masyarakat AS karena tidak diberitakan oleh media AS. Dalam konferensi yang dihadiri para ulama dari berbagai negara Muslim, antara lain Grand Imam Muhammad Sayyid Tantawi (ulama besar dari kalangan Sunni, mufti Al Azhar Kairo) dan Grand Ayatollah Sheikh Ali alHusseini al-Sistani (pemimpin paling berpengaruh di tengah kaum Syiah Irak) itu dirilis deklarasi penolakan atas aksi terorisme (Kimball, 2003:266).

Kimball menyarankan agar para pemuka agama Islam terus mencari cara-cara untuk menyampaikan pesan yang jelas dan tegas kepada kelompok-kelompok ekstrimis; menjelaskan kepada mereka prinsip Islam yang damai dan penolakan kepada terorisme. Masa depan negara-negara mayoritas Muslim sangat bergantung pada kestabilan politik, ekonomi, dan budaya yang bisa diraih melalui sistem yang terbuka dan demokratik.

\section{Kesimpulan}

Setelah mengkaji berbagai fenomena aksi kekerasan atas nama agama yang terjadi di berbagai penjuru dunia, di tengah umat dari berbagai agama, Kimball menyimpulkan bahwa ada lima tanda agama yang menunjukkan agama telah melenceng dipahami sehingga berujung pada bencana. Kelima tanda itu adalah klaim kebenaran mutlak, kepatuhan buta, membangun zaman baru, tujuan menghalalkan segala cara, dan menyerukan perang suci.

Khusus untuk contoh-contoh kasus di Timur Tengah yang dianalisis Kimball dengan menggunakan perspektif sejarah, budaya, dan politik, Kimball menjelaskan bagaimana banyak umat Muslim merasa dikalahkan dalam percaturan politik dan ekonomi dunia. Mereka berupaya melawan kekuatan mapan yang tengah melakukan rekolonisasi dengan menggunakan agama sebagai identitas untuk menyatukan mereka. Namun ada sebagian kelompok yang memiliki penafsiran berbeda dari 
penafsiran arus-utama dan memahami agama dengan 'lima tanda' bahaya tersebut sehingga berujung pada aksi-aksi terorisme. Bagi kelompok ini, agama telah menjadi alat politik semata. Dan sebagai sebuah alat, sebagaimana benda lain, ia hanya digunakan ketika sang pelaku memerlukannya. Aksi-aksi terorisme adalah aksi di luar ajaran agama secara tekstual ataupun kontekstual.

\section{Daftar Pustaka}

Antara News. (2015). Korban Tewas Akibat Konflik di Palestina Capai Angka Tertinggi. [online] Dalam: https://www.antaranews.com/berita/487532/korban-tewasakibat-konflik-di-palestina-capai-angka-tertinggi [Diakses 6 Des. 2017].

Antara News. (2017). Israel Lanjutkan Pembangunan Permukiman, Langgar Resolusi PBB. [online] Dalam: https://www.antaranews.com/berita/672033/israellanjutkan-pembangunan-permukiman-langgar-resolusi-pbb [Diakses 19 Des. 2017].

Bagir, Haidar. 2017. Islam Tuhan Islam Manusia. Bandung: Mizan

Hamdani, Mahmood. (2006). Islam, Terorisme, dan Proyek Politik Internasional. Dalam Ahmad Norma Permata, ed., Agama dan Terorisme. Surakarta: Muhammadiyah University Press.

Jewish Virtual Library. (2017). Zionism: Neturei Karta. [online] Dalam: http://www. jewishvirtuallibrary.org/neturei-karta [Diakses 19 Des. 2017].

Kemenag. (2014). Al-Qur'an terjemah \& tajwid. Bandung: Sygma.

Kimball, Charles. Biographical Sketch. [online] Dalam: http://charles-kimball.com/ about [Diakses 6 Des. 2017].

Kimball, Charles. (2003). Kala Agama Jadi Bencana terj. Nurhadi. Bandung: Mizan.

Naharong, Abdul Muis. (2013). Terorisme Atas Nama Agama. Jurnal Refleksi, Vol. 13, No. 5.

Pew Research Center. 2017. Terrorism and concerns about extremism. Pew Forum. Dalam http://www.pewforum.org/2017/07/26/terrorism-and-concerns-aboutextremism/ [Diakses 6 Des. 2017]. 
Undang-Undang Nomor 15 Tahun 2003 Tentang Pemberantasan Tindak Pidana Terorisme. Dalam http://peraturan.go.id/inc/ view/11e44c4e29228eb0a1d1313231323130.html [diakses 1 Desember 2017] 